\title{
O dREETO AO CASAMENTO E à SUA DISSOLUÇÃO ENTRE OS DIREITOS FUNDAMENTAIS DO INDIVÍDUO (")
}

\author{
ACCIOLY FILHO (**) \\ Os excessos cometidos em nome da liberdade \\ podem fazê-la odiosa, porém não são obstáculo \\ para que ela seja bela e necessária.
}

(Tocqueville)

1. O elenco de direitos fundamentais é a garantia, para o homem, de instrumentos com os quais possa, na sociedade e em confronto com os semelhantes e com o Estado, ter liberdade e conquistar a sua felicidade.

2. A realização da felicidade pessoal de cada cidadão é o fim último da democracia e do direito. Platão já escrevia que ao direito não interessa existir na cidade só uma classe que goze de particular felicidade, mas aspira que isso ocorra com a cidade inteira (Platão - República, 519 e 520).

Mas, essa possibilidade de conquista da felicidade, repousa fundamentalmente no respeito à personalidade do indivíduo, que deve desenvolver-se e projetar-se livremente. Era como Aristóteles entendia o ser humano: um ser unitário, que não deve ser olhado como objeto no processo social, mas como sujeito e fonte de valores.

3. O Estado democrático tem essa preocupação de resguardar o livre descobrimento da personalidade do indivíduo.

Essa preocupação estava estampada na Declaração de Direitos do Povo da Virgínia, de 12 de Junho de 1776, e que veio fazer parte da Constituição daquele Estado: "Que todos os homens são por natureza igualmente livres e independentes e têm certos direitos inatos, dos quais não podem ser privados e que são: 0 gozo da vida e da liberdade, com os meios de adquirir e possuir a propriedade e obter a felicidade e a segurança".

$\left(^{\star}\right)$ Tese apresentada à VII Conferência Nacional da OAB.

(**) Senador da República pelo Paraná. 
E poucos anos mais tarde, em 24 de junho $d$ el793, era o povo Francês que mostrava ser a felicidade o fim das instituições políticas. Escrevia-se, então, iá no artigo $1 . .^{\circ}$ da Declaração dos Direitos do Homem e do Cidadão: "A meta da sociedade é a feiicidade comum".

Outrora, já Tocqueville tinha essa visão da democracia, pois, se nela divisava a igualdade de direitos políticos e igualdade perante a Lei, também ressaltava que ela propiciava grande independência deixada ao indivíduo (a maior possível), liberdade total, responsabilidade total, facilidade total.

4. É certo que para se ter essa conceituação da função do Estado democrático, não é preciso ir ao extremo da doutrina de Dunoyer, economista do século passado, segundo a qual à autoridade estatal resta apenas uma missão - a de pordutor de segurança, de cujo bem os cidadãos são os consumidores. Basta restringir a atividade estatal, naquilo que toca à pessoa dos cidadãos, ao mínimo indispensável à prática preservação da personalidade de cada um e obediente ao respeito à dignidade do ser humano.

5. O Estado não deve ser modelado segundo a doutrina de Mussolini - tudo no Estado, nada fora do Estado, nada contra o Estado, - porque isso é a síntese do totalitarismo, em que se anula o indivíduo para dar corpo inteiro ao Estado, que passa a ser a única realidade e o único endereço das preocupações da sociedade. Desaparece 0 indivíduo como fonte de valores, com sua liberdade alienada e tendo de conter a natural expansão de sua personalidade para submeter-se aos valores do Estado.

Nem pode o Estado voltar-se preferencialmente aos valores gerados pela Raça, pelo Povo, pela Nacionalidade, segundo a doutrina de Hitler, que dizia ao cidadão - "Tu não és nada; o teu Povo é łudo". Essa doutrina teria de levar, nas suas conseqüências, ao racismo, à abulia individual e à inteira, submissão do indivíduo aos interesses do povo, que passava a ser um Deus devorador, exigente, caprichoso; intolerante e feroz.

A simples menção das doutrinas que informam os Estados que não optam pela democracia liberal, já mostra que, além de não terem sobrevivência, os regimes não democráticos, ao anular o indivíduo, não conseguem desenvolver a nação.

6. Para acentuar esse aspecto do Estado democrático - o do primado da personalidade humana -, contribuiu a trabalhada conceituação dos Direitos Humanos que, ao longo do tempo, se fo- 
ram corporificando nas Declarações de Direitos dos textos constitucionais. Angel de la Torre mostra que entre os traços constantes de uma comunidade política aparecem sempre como valores jurídicos a liberdade e a felicidade, comprendidos ambos em um conceito comum: dignidade humana. A conquista e a preservação dessa dignidade humana é que marcam e resumem todo o processo da história humana, e sobre ela se constitui a unidade histórica da humanidade. (Teoria jurídica de los Derechos humanos, II Sociologia de los derechos humanos).

Quando a Unesco encarregou-se de colher subsídios para a redação da Declaração Universal dos Direitos do Homem, Arnold Lien mostrou que "as novas formulações dos direitos do homem no século $\mathrm{XX}$, tal como se encontram em numerosos estafutos de direi.os nas novas Constituições, distinguem-se das antigas especialmeñ̂e pela importância dada aos aspectos sociais e econômicos. Os direíos fundamentais são os mesmos, mas as preocupações peculiares à nova época trouxeram uma substituição do priniado do políiico peio econômico, da liberdade pela igualdade e a segurança". (Los Derechos del hombre, coletânea da Unesco).

7. Da própria experiência humana, aliada aos ensinamentos de filósofos, resultou a construção vagarosa do elenco dos direitos humanos.

De que precisava o homem para resguardar sua personalidade e desenvolvê-la e expandí-la segundo suas próprias inclinaçõas?

Como ser sujeito, criador e formador do Estado e dele partícipe?

Como impedir que uns se avantajem sobre outros na participação no Estado, com direitos e deveres diversos?

Como deter a tendência expansionista do homem e da sua creatura, o Estado, na invasão sobre a área de atividade piivativa de cada um?

A proporção que ia sentindo e se defrontando com questões como essas, a sabedoria humana foi produzindo normas jurídicas que pudessem defender os indivíduos desses males oriundos da organização social.

Hoje não se pode dizer se a sociedade se aprimorou porque se aperfeiçoou a defesa da dignidade humana ou se, ao contrário, esse aperfeiçoamento é que deu causa ao aprimoramento da vida social e ao acelerado desenvolvimento material, ou, afinal, se foi 
menos só detinham a imagem do homem oslitário. Voltavám-se as um simultâneo progresso com recíprica influência.

8. De início, as normas jurídicas protetoras dos direitos husuas preocupações para o ser humano em sua vida na sociedade, preservando o das violências à sua liberdade física ou à sua liberdade espiritual e garantindo a igualdade dos membros da comunidade social.

Aos poucos, a área de defesa dos direitos humanos ampliou-se à medida em que se tornou possível ao Estado perturbar, em atividades novas que surgiam, a liberdade dos indivíduos, e ao mesmo tempo em que se verificou que certas liberdades se tornavam vazias se não se garantisse o homem das necessidades naturais.

9. No entanto, o cuidado continuava sempre a respeito do homem iso!ado, não porque o legislador não tivesse a visão da imagem bíblica - a do casal, mas porque a preocupação era exatamente de defender o indivíduo como pessoa humana, destacando o do grupo social e dele fazendo fonte de valores.

No longo elenco de garantias relativas aos direitos humanos, não há no texto constitucional uma que se refira mesmo indiretamente à liberdade do casamento, e a sua proteção como valor individual.

Tivemos, na primeira Constituição Republicana, inserida na Declaração de Direitos, uma norma a propósito do casamento. Mas, o endereço não era o resguardo do matrimonio como direito individual e tão só pôr fim, também no texto constitucional, ao casamento religioso.

Está expresso no $\operatorname{artg} .72, \S 44^{\circ}$, daquela Constituição que "A República só reconhece o casamento civil, cuja celebração será grałuiła".

Alí estava posto o casamento para contrapor o civil ao religioso e nada mais do que isso, salvo a preocupação da gratuidade, que, sovinamente, só alcançava o ato da celebração.

$\mathrm{Na}$ Constituição de 1934, nem siquer o casamento continuou a figurar sob o título das garantias individuais. Passou a constituir uma norma incluída no título "Da Família" e agora sem a preocupação de ôpor o matrimonio civil ao religioso, porque se admitiam os efeitos civis a este último. Restou tão só a preocupação pela gratuidade, como se isso bastasse para torná-lo acessível a todos, mas se acresceu, no art. 144, o caráter indissolúvel do casamento. 
Constituição de 1934 - Da Família.

"Art. 146 - O casamento será civil e gratuita a sua celebração..."

No texto de 1937, manteve-se o casamento no título "Da Família" e não mais se fala em matrimonio civil nem em gratuidade, mas perdura a condição de indissolubilidade.

Constituição de 1937 - da Família.

"Art. 124 - A família, constituída pelo casamento indissolúvel, está sob a prołeção especial do Estado".

A Constituição de 1946 não modificou as normas do texto anterior relativas ao casamento. Manteve-o num título sobre "Família, Educação e Cuitura", não suprimiu a indissolubilidade, mas fez retornar a gratuidade da sua celebração.

Constituição de 1946 - Da Família, da Educação e da Cultura.

"Art. 163 - A família é constituída pelo casamento de vínculo indissolúvel e terá dirieto à prołeção especial do Estado".

$\S 10^{\circ}$ - 0 casamento será civil e gratuita a sua celebração..."

Na Constituição de 1967, o casamento continuou a ser objeto de um título diverso daquele da declaração de direitos e se manteve com o mesmo texto da anterior.

Constituição de 1967 - Da Família, da Educação e da Cultura.

Art. 167 - A família é constituída pelo casamento e terá direito à proteção dos Poderes Públicos.

$\S 1 .^{\circ}-0$ casamento é indissolúvel.

$\S 2 .^{\circ}$ - O casamento será civil e gratuita a sua ceiebração..."

Elevou-se a indissolubilidade a regra autônoma e ainda, quanto à pessoa dos numbentes, a única preocupação era a da gratuidade da celebração do matrimônio.

Emenda Constitucional n. 9

"Art. 175, § $10^{\circ}$ - O casamento somente poderá ser dissolvido, nos casos expressos em Lei, desde que haja prévia separação judicial por mais de três anos" 
10. Aquilo que chama a atenção em todos os textos constitucionais da nossa vida republicana, a respeito do casamento, é a sua conceituação como instituto de interesse social, em que sobrelevam os cuidados pelo que ele representa para a sociedade.

11. A omissão de nosso legislador, em contraste com os documentos internacionais sobre os direitos humanos e dos textos constitucionais de outros países, parece revelar ainda a manutenção da antiga postura em face do casamento e da família. A família, como escreve Jean Carbonnier, antigamente era uma unidade fechada à sociedade, afirmava-se mesmo contra a sociedade e extraia dessa independência e dessa oposição mais coesão e mais força; agora, no entanto, todas as relações familiares são invadidas por intervenção do Estado (Flexible Droit).

Não atenderam os nossos legisladores à observação feita por Jacques Maritain, em sua contribuição à Declaração Universal dos Direitos Humanos - Convém, em uma Declaração de Direitos, assinalar, de forma precisa, os direitos e liberdades que se retiram à sociedade familiar (ob. cit.).

A Constituição de Weimar já continha, na parte dos Direitos e Deveres Fundamentais dos Alemães, norma reguladora do casamento, colocando-o sob a proteção especial da Constituição:

"Art. 119 - 0 matrimônio, fundamento da vida familiar e da manutenção e crescimento na Nação, está sob a proteção especial da Constituição e se baseia na igualdade jurídica de ambos os sexos".

Antes de ser votada e aprovada a Declaração Universal pela ONU, já a Constituição Italiana de 27 de dezembro de 1947 fazia também inscrever, na parte de Direitos e Deveres dos Cidadãos, regras a respeito da família e do casamento, assegurando o primado dos seus direitos:

"Art. 29 - A República reconhece os direitos da família como sociedade natural fundada no matrimonio. $O$ casamento será regulado sobre a igualdade moral e jurídica dos cônjuges, com as limitações estabelecidas na Lei para garantir a unidade famliar".

12. Idêntica veio a ser a preocupação da Constituição Alemã de 1949, já promulgada a Declaração Universal. No texto constitucional alemão, a norma de que o casamento e a família gozam de proteção particular do Estado (art. 6.1) também faz parte do Título dos Direito Fundamentais. 
13. Já na Declaração Americana dos Direitos e Deveres do Homem, assinada em Bogotá a 2 de maio de 1948, os povos americanos, com base no texto da Convenção Universal, então elaborado, proclamaram que:

"Art. 6..$^{\circ}$ - Toda pessoa tem direito a constituir família, elemento fundamental da sociedade, e a receber proteção para ela".

14. Mas, foi na Declaração Universal dos Direitos Humanos (10 de dezembro de 1948) que o direito ao casamento se consagrou definitivamente no elenco das garantias fundamentais. Resultado de uma colaboração das figuras mais expressivas da inteligência humana, aquele texto recolheu a contribuição dos maiores pensadores, cientistas, artistas e políticos. Poucos entenderam dever ser restrita ou sintética a Declaração. Com exceção do Mahatma Gandhi, que, por não dispor de tempo para o trabalho pedido pela Unesco, opinava para que a Declaração contivesse os direitos correspondentes aos deveres do homem, todos se pronunciaram pela atualização das normas garantidoras do livre desenvolvimento da personalidade humana.

15. Por isso, vista numa optica total, abrangendo de todos os aspectos em que se manifesta, a personalidade humana teria de ser garantida também na sua natural vocação para a comunhão de vida entre pessoas de sexo diferente, destinada à procriação e à permuta de afeição.

Se o direito apanhou o fato natural dessa comunhão e o regulou, é preciso que o indivíduo seja defendido contra o excesso de intervenção do Estado e que a regulação do fenômeno não o transforme de manifestação espontânea da personalidade em dever perante o Estado, de direito do cidadão em exclusivo interesse da sociedade.

16. Com essa preocupação, a Declaração Universal foi explícita a respeito dos direitos do indivíduo relativos ao casamento. Assim:

"Art. 16. 1. - Os homens e as mulhenes, a partir da idade núbil, têm direito, sem restrição alguma por motivo de raça, nacionalidade ou religião, de casar-se e fundar uma família, e desfrutarão de iguais direitos quanto ao matrimônio, durante o matrimônio e em caso de dissolução do matrimônio. 
2. - Só mediante livre pleno consentimento dos futuros esposos poderá contrair-se o matrimônio.

3. - A família é o elemento natural e fundamenta da sociedade e tem direito à "proteçáo da sociedade e do Estado". (Declaração Universal dos Direitos do Homem).

A Declaração procurou, como se vê, atingir a todos os aspectos dos direitos do homem acerca do casamento, invertendo a direção das preocupações para centrá-la na pessoa humana antes de ser a sociedade sua destinatária. A constitúição da família, para a Declaração, é sobrétudo um direito do indivíduo, com o qual ele procura expandir sua personalidade e realizar uma vocação, cumprindo ao Estado tão só facilitar a obtenção desse direito e regulá-lo para o seu exercício. A partir da vigência da Declaração, as naçốes, na elaboração de documentos internacionais destinados a dar execução aos princípios firmados no ato da Declaração, mantiveram reiteradamente as normas a respeito do direito ao casamento.

Assim, na Convenção de Salvaguarda dos Direitos do Homem e das Liberdades Fundamentais, assinada em Roma a 4 de novembro de 1950, está repetida parte do texto da Declaração:

"Art. 12 - A partir da idade núbil, a homem e a mulher têm o direito de casar-se e de fundar uma família segundo as heis nacionais que regem o exercício desse direito".

Também na Carta Social Européia, firmada em Turim a 18 de outubro de 1961, prevaleceu a mesma preocupação da Declaração:

"Art. 16 - A fim de realizar as condições de vida indispensáveis para o pleno desenvolvimento da família, as partes contratantes se comprometem a promover a "proteção econômica, jurídica e social da família, em particuliar por meio... de ajuda aos matrimônios de jovens"t.

Após oito anos de vigência da Declaração, eram as suas normas que prevaleciam no Pacto Internacional de Direitos Civis e Políilicos, firmado em N. York a 16 de dezembro de 1966:

"Art. 23. 1. - A família é o elemento nałural e fundamental da sociedade e tem direito à prołeção da comunidade e do Estado.

2. - Reconhece-se o direito do homem e da mulher de contrair matrimônio e de fundar uma família se têm idade para isso. 
3. - O matrimonio nằo poderá ceiebrar-se sem o livre e pleno consetimento dos contraentes.

4. - Os Estados partes no presente Pacło tomarão as medidas apropriadas para assegurar a igualdade de direitos e de responsabilidades de ambos os esposos quanto ao matrimonio, duranłe o matrimonio e no caso de dissolução dele: Em caso de dissolução, adotar-ş?:ão disposições que assegurem a porteção necessária aos filhos".

No Pacto Internacional de Direitos Econômicos, Sociais e Culturais, assinado conjuntamente com o Pacto acima em parte transcrito, não foi diferente a intenção das partes signatárias:

"Art. 10 - Os Estados paries no presente Pacto reconhecem que:

1. - Deve-se reconhecer à família, que é o elemento natural e fundamental da sociedade, a mais ampla proteção e assistência possíveis, especialmente para sua constituição e enquanto seja responsável pelo cuidado e educação dos filhos a seu cargo. O matrimonio deve contrairse com o livre consentimento dos futuros esposos".

Afinal, vinte e dois anos depois da Declaração, esta é que dominava ainda o texto da Convenção Americana sobre Direitos Humanos, asinada em S. José da Costa Rica a 7 de abril de 1970.

"Art. 17 - A família é o elemento natural e fundamental
da sociedade e deve ser protegida pela comunidade e pe-
lo Estado.

2. - Reconhece-se o direito do homem e da mulher de contrair matrimonio e fundar uma família se têm a idade e as condições requeridas para isso pelas leis internas, na medida em que estas não afetem o princípio da não discriminação estabelecido nesta Convenção".

17. Vê-se, dessa longa transcrição de textos internacionais referentes aos direitos humanos, que o direito ao casamento deles passou a ser definitivamente integrante.

Essa inclusão não foi arbitrária, mero capricho dos elaboradores da Declaração, mas simples proclamação de ser o casamento uma necessidade do ser humano e de que deve ser resguardada a sua liberdade. 
O nosso direito constitucional jamais teve esse cuidado e simplesmente vem desconhecendo o casamento como dirito do individuo. Regula-o, no texto constitucional, como instituto que interessa à sociedade, mas não como direito que pertence ao cidadão e que deve ser protegido.

18. De igual modo, a dissolução do casamento é tratada como uma concessão feita pelo Estado, para permitir que, em limitados casos, ao indivíduo seja possível instituir nova família, após o insucesso de um matrimonio.

19 .. De tudo quanto se expôs, resulta uma PROPOSIÇÃO:

- O CASAMENTO E DIREITO DO INDIVÍDUO E DEVE SER RESGUARDADO ENTRE OS DIREITOS FUNDAMENTAIS. 